\title{
Performance of 'Oneco' mandarin on six rootstocks in South Brazil
}

\author{
Mateus Pereira Gonzatto(1), Alisson Pacheco Kovaleski(1), Eduardo Cesar Brugnara(2), Roberto Luis Weiler ${ }^{(1)}$, \\ Ivar Antônio Sartori ${ }^{(3)}$, Jurandir Gonçalves de Lima ${ }^{(4)}$, Renar João Bender ${ }^{(1)}$ and Sergio Francisco Schwarz ${ }^{(1)}$ \\ (1)Universidade Federal do Rio Grande do Sul, Faculdade de Agronomia, Departamento de Horticultura e Silvicultura, Programa de Pós-graduação \\ em Fitotecnia, Caixa Postal 15.100, CEP 91501-970 Porto Alegre, RS, Brazil. E-mail: mpgonzatto@gmail.com, apkovaleski@gmail.com, \\ robertoluisw@yahoo.com.br, rjbe@ufrgs.br, schwarz@ufrgs.br (2)Empresa de Pesquisa Agropecuária e Extensão Rural de Santa Catarina, \\ Centro de Pesquisa para Agricultura Familiar, Caixa Postal 791, CEP 88965-970 Chapecó, SC, Brazil. E-mail: edubrugnara@ibest.com.br \\ (3)Instituto Federal de Educação, Ciência e Tecnologia Catarinense, Rua das Missões, no 100, Ponta Aguda, CEP 89051-000 Blumenau, SC, \\ Brazil. E-mail: ivar@ifc.edu.br ${ }^{(4)}$ Fazenda Panoramas Citrus, CEP 96950-970 Butiá, RS, Brazil. E-mail: jgdelima@ibest.com.br
}

\begin{abstract}
The objective of this work was to assess the effect of six rootstocks on yield, fruit quality, and growth of 'Oneco' mandarin during the first seven harvesting seasons, in Butiá, Rio Grande do Sul State, Brazil. The rootstocks evaluated were: 'Swingle' citrumelo (Citrus paradisi $\times$ Poncirus trifoliata), 'Caipira' orange $(C$. sinensis $)$, 'Troyer' citrange $(C$. sinensis $\times P$. trifoliata), 'Rangpur' lime (C. limonia), 'Volkamer' lemon (C. volkameriana), and 'Flying Dragon' trifoliata orange (P. trifoliata var. monstrosa). Plants budded onto 'Flying Dragon' had the lowest vegetative development, which indicates the dwarfing characteristics of this rootstock, and had the highest mean production efficiency, despite low yield. Plants grafted on 'Volkamer' lemon and 'Rangpur' lime had the highest alternate bearing. Under the experimental conditions evaluated, the most adequate rootstocks for mandarin 'Oneco' are 'Swingle' citrumelo and 'Troyer' citrange, regarding fruit yield and quality.
\end{abstract}

Index terms: Citrus reticulata, alternate bearing, fruit quality, yield.

\section{Comportamento da tangerineira 'Oneco' sobre seis porta-enxertos no Sul do Brasil}

Resumo - O objetivo deste trabalho foi avaliar o efeito de seis porta-enxertos sobre a produção, a qualidade dos frutos e o crescimento da tangerineira 'Oneco', durante as sete primeiras safras, em Butiá, Rio Grande do Sul. Os porta-enxertos avaliados foram: citrumeleiro 'Swingle' (Citrus paradisi $\times$ Poncirus trifoliata), laranjeira 'Caipira' (C. sinensis), citrangeiro 'Troyer' (C. sinensis $\times$ P. trifoliata.), limoeiro 'Cravo' (C. limonia), limoeiro 'Volkameriano' (C. volkameriana) e trifoliata 'Flying Dragon' (P. trifoliata var. monstrosa). As plantas enxertadas sobre 'Flying Dragon' apresentaram menor desenvolvimento vegetativo, o que indica as características nanizantes deste porta-enxerto, e obtiveram a maior eficiência produtiva média, apesar da baixa produção. As plantas enxertadas sobre os limoeiros 'Volkameriano' e 'Cravo' apresentaram as maiores alternâncias de produção. Nas condições experimentais avaliadas, os melhores porta-enxertos para a tangerineira 'Oneco' são o citrumeleiro 'Swingle' e o citrangeiro 'Troyer', no que se refere à produção e à qualidade dos frutos.

Termos para indexação: Citrus reticulata, alternância de produção, qualidade de fruto, produtividade.

\section{Introduction}

'Oneco' mandarin (Citrus reticulata Blanco) is a selection of 'Ponkan' mandarin, which occupies 58\% of the mandarin-producing area in Brazil (Amaro \& Caser, 2003). In general, 'Oneco' is very similar to 'Ponkan', which has a columnar tree canopy, with high yields, and a tendency to alternate bearing (Stenzel et al., 2003).

'Oneco' was identified as a potential alternative cultivar to 'Ponkan', due to its high productivity and longer harvesting period evidenced by a higher capacity of fruit storage (Sartori et al., 1998). Furthermore, 'Ponkan' has a very concentrated harvesting period that contributes to the rise of seasonal prices (Amaro \& Caser, 2003). However, there is a lack of information on the effects of different rootstocks on 'Oneco' mandarin fruit quality, tree development and productivity.

Rootstocks affect canopy growth and development, production, and fruit quality in citrus, as well as tolerance to various stresses (Castle, 1987). 'Rangpur' lime (Citrus limonia Osbeck) is the main rootstock in Brazil, and is used in $80 \%$ of Brazilian citrus orchards because of its drought tolerance (Pompeu Júnior, 2005).

Pesq. agropec. bras., Brasília, v.46, n.4, p.406-411, abr. 2011 
However, in Rio Grande do Sul state, Poncirus trifoliata (L.) Raf is the most common rootstock, due to its greater cold-hardiness; and at least $90 \%$ of the citrus trees in the state are budded onto this rootstock (Schäfer et al., 2001a).

High disease incidence, to which rootstock resistance is crucial, has prompted the need to investigate rootstock assortment. Diseases, such as citrus tristeza virus, gummosis (Phytophthora sp.), and citrus sudden death, reinforce the call for research on diverse citrus species and hybrids as potential rootstock material.

The objective of this work was to assess the effect of six rootstocks on yield, fruit quality, and growth of 'Oneco' mandarin during the first seven harvesting seasons, in Butiá, Rio Grande do Sul state, Brazil.

\section{Materials and Methods}

'Oneco' mandarin was budded onto six rootstocks: 'Swingle' citrumelo [Citrus paradisi Macfad $\times$ $P$. trifoliata], 'Caipira' orange (C. sinensis Osbeck), 'Troyer' citrange $(C$. sinensis $\times P$. trifoliata $)$, 'Rangpur' lime (C. limonia Osb.), 'Volkamer' lemon (C. volkameriana Ten. \& Pasq.), and trifoliata 'Flying Dragon' orange $[P$. trifoliata var. monstrosa (T. Ito) Swing.].

The experiment was carried out in a private grove $\left(30^{\circ} 07^{\prime} 5^{\prime \prime} \mathrm{S}, 51^{\circ} 51^{\prime} 22^{\prime \prime} \mathrm{W}\right)$ close to the city of Butiá, about $70 \mathrm{~km}$ west of Porto Alegre, Rio Grande do Sul State, Brazil. The soil is classified as Paleudult (United States Department of Agriculture, 1999), and the climate as $\mathrm{Cfa}$, according to Köppen. The average annual temperature is $19.2^{\circ} \mathrm{C}$, and the average temperatures of the coldest (June) and warmest (January) months are 13.5 and $24.6^{\circ} \mathrm{C}$, respectively. Annual rainfall is approximately $1.440 \mathrm{~mm}$ (Bergamaschi et al., 2003).

Trees were planted in August 1997, in a $6.0 \times 2.5 \mathrm{~m}$ spacing, with 667 trees per hectare. The experiment was managed according to the usual cultural practices (Koller, 2009), with plants being hand-thinned every year between February and March, and pruned in the winter of 2004 to eliminate dead wood and crooked branches.

Individual measurements of tree height $(\mathrm{H})$, perpendicular $\left(D_{r}\right)$ and parallel $\left(D_{l}\right)$ canopy diameters, and trunk circumference at $5 \mathrm{~cm}$ above the bud union were taken from 2003 to 2007, after the summer growth flush. Canopy volume (V) was calculated using the formula:

$$
\mathrm{V}=(\pi / 6) \times \mathrm{H} \times \mathrm{D}_{1} \times \mathrm{D}_{\mathrm{r}} \text { (Zekri, 2000) }
$$

Production efficiency $\left(\mathrm{kg} \mathrm{m}^{-3}\right)$ was determined by the ratio of total fruit mass to canopy volume. The canopy projection area (CPA) was calculated using the formula $\mathrm{CPA}=\pi\left[\left(\mathrm{D}_{1}+\mathrm{D}_{\mathrm{r}}\right) / 4\right]^{2}$ (Schäfer et al., 2001b). An alternate bearing index (ABI) was calculated as described by Stenzel et al. (2003):

$$
\begin{gathered}
\text { ABI }=\left[(1 /(\mathrm{n}-1)] \times\left\{\left[\left|\left(\mathrm{a}_{2}-\mathrm{a}_{1}\right)\right| /\left(\mathrm{a}_{2}+\mathrm{a}_{1}\right)\right]\right.\right. \\
\left.+\left[\left|\left(\mathrm{a}_{3}-\mathrm{a}_{2}\right)\right| /\left(\mathrm{a}_{3}+\mathrm{a}_{2}\right)\right]+\ldots+\left[\left|\left(\mathrm{a}_{\mathrm{n}}-\mathrm{a}_{\mathrm{n}-1}\right)\right| /\left(\mathrm{a}_{\mathrm{n}}+\mathrm{a}_{\mathrm{n}-1}\right)\right]\right\},
\end{gathered}
$$

in which $\mathrm{n}$ is the number of years, and $\mathrm{a}_{1}, \mathrm{a}_{2}, \ldots, \mathrm{a}_{\mathrm{n}-1}$, $\mathrm{a}_{\mathrm{n}}$ is the yield per tree in the corresponding year. The $\mathrm{ABI}$ ranges from 0 to 1 , and the closest it is to 0 , the less variation there is in yield between years. This trait was evaluated for the following periods: $2001 / 2003$, 2002/2004, 2003/2005, 2004/2006, 2005/2007, 2001/2004, 2004/2007, and 2001/2007.

Fruit harvest occurred from 2001 to 2007. Total annual yield per tree and accumulated yield were calculated for this period. Starting in 2002, 20 fruits harvested from each replicate of each treatment were randomly selected to determine fruit quality. The measurements taken were: juice content (JC, $\%$ ), calculated by the difference of mass between juice and fruits; total soluble solids (TSS), with a table refractometer; and titratable acidity (TA, \% of citric acid), determined by titration of $10 \mathrm{~mL}$ juice diluted in $90 \mathrm{~mL}$ of distilled water up to $\mathrm{pH}$ 8.1. Mass (M), length (L), and diameter (D) of individual fruits were also determined, in which $\mathrm{L}$ and $\mathrm{D}$ were used to estimate fruit shape through the ratio L:D.

The experiment was set up in a completely randomized block design with four replicates and four trees as an experimental unit, for each rootstock. Data for total yield, vegetative growth, and fruit quality were analyzed using analysis of variance, and means were compared with Duncan's multiple range test, at $5 \%$ probability.

\section{Results and Discussion}

Annual yield (Table 1) was affected by rootstocks, except in 2002 and 2006, when production was low and variable due to alternate bearing. In general, trees on 'Swingle' consistently had greater yields than those on the other rootstocks. Trees budded onto 'Rangpur' and 'Swingle' were the most precocious, having the highest yields in 2001. The highest cumulative yields 
were found for trees grafted on 'Swingle', whereas no significance was found for yields of trees on 'Caipira', 'Troyer', or 'Rangpur'. The lowest cumulative yields were obtained for plants budded onto 'Flying Dragon', while plants on 'Volkamer' had intermediate yields. Stenzel et al. (2003), who compared seven rootstocks for 'Ponkan' mandarin grown in Paraná state, Brazil, also found equivalent yields for plants grafted on 'Rangpur' lime and 'Volkamer' lemon, while plants on P. trifoliata had the lowest yields. Mourão Filho et al. (2007) observed that cumulative yield for plants budded on 'Rangpur' lime was higher than for plants on 'Swingle'. Georgiou (2000), while evaluating 'Nova' mandarin, reported that plants grafted on 'Volkamer' lemon were superior to those on 'Swingle' and 'Troyer'.

The highest ABI was found for trees budded on 'Volkamer' lemon and 'Rangpur' lime (Table 2), which indicates that these rootstocks have the least constant production. These results are contrary to those obtained by other authors (Georgiou, 2000; Smith et al., 2004; Espinoza-Núñez et al., 2007; Mourão Filho et al., 2007). Stenzel et al. (2003) found low ABIs for 'Ponkan' grafted onto citrange $\mathrm{C}-13$ and $P$. trifoliata. Espinoza-Nuñez et al. (2008), who evaluated 'Fairchild' mandarin, also obtained highest ABI for plants budded on 'Rangpur' lime, as in the present work. However, Stuchi et al. (2008) and Cantuarias-Avilés et al. (2010) found the lowest ABI, respectively, for 'Swatow' mandarin and 'Okitsu' satsuma grafted on 'Rangpur' lime.

The ABIs were affected by rootstocks especially during the first years of the orchard's production. No effect from the rootstocks was observed in 2004/2007, which indicates that this effect can be associated with initial plant yield instability (Smith et al., 2004).

Table 1. Annual and cumulative yields, and production efficiency of 'Oneco' mandarin grafted onto six different rootstocks grown in Butiá, Rio Grande do Sul state, Brazil ${ }^{(1)}$.

\begin{tabular}{|c|c|c|c|c|c|c|c|c|}
\hline Rootstock & 2001 & 2002 & 2003 & 2004 & 2005 & 2006 & 2007 & Cumulative \\
\hline & \multicolumn{8}{|c|}{ Yield (kg per tree) } \\
\hline 'Swingle' citrumelo & $22.1 \mathrm{ab}$ & 5.5 & $50.1 \mathrm{a}$ & $20.8 \mathrm{ab}$ & $21.5 \mathrm{a}$ & 7.8 & $52.4 \mathrm{a}$ & $180.1 \mathrm{a}$ \\
\hline 'Caipira' orange & $19.3 b$ & 6.0 & $50.5 \mathrm{a}$ & $17.2 b$ & $20.5 \mathrm{a}$ & 9.8 & $41.1 \mathrm{ab}$ & $164.4 \mathrm{a}$ \\
\hline 'Troyer' citrange & $10.3 \mathrm{~cd}$ & 10.0 & $29.5 b$ & $24.4 \mathrm{a}$ & $15.6 \mathrm{a}$ & 17.4 & $49.4 \mathrm{a}$ & $156.7 \mathrm{a}$ \\
\hline 'Rangpur' lime & $29.1 \mathrm{a}$ & 4.9 & $54.4 \mathrm{a}$ & $8.3 \mathrm{c}$ & $18.3 \mathrm{a}$ & 2.3 & $33.5 b$ & $150.8 \mathrm{a}$ \\
\hline 'Volkamer' lemon & $16.3 \mathrm{bc}$ & 1.5 & $33.9 b$ & $6.5 \mathrm{c}$ & $13.7 \mathrm{ab}$ & 12.0 & $32.4 b$ & $116.4 b$ \\
\hline 'Flying Dragon' trifoliate orange & $4.7 \mathrm{~d}$ & 2.4 & $13.3 \mathrm{c}$ & $6.9 \mathrm{c}$ & $6.1 \mathrm{~b}$ & 22.1 & $16.3 \mathrm{c}$ & $71.8 \mathrm{c}$ \\
\hline \multirow[t]{2}{*}{$\mathrm{P}$} & $<0.0001$ & 0.11 & $<0.0001$ & $<0.0001$ & 0.0097 & 0.45 & 0.0002 & $<0.0001$ \\
\hline & \multicolumn{8}{|c|}{ Production efficiency $\left(\mathrm{kg} \mathrm{m}^{-3}\right)$} \\
\hline 'Swingle' citrumelo & - & - & $11.0 \mathrm{ab}$ & $5.4 \mathrm{ab}$ & 4.8abc & 1.3 & 4.9 & $27.5 b$ \\
\hline 'Caipira' orange & - & - & $10.6 \mathrm{ab}$ & $5.2 \mathrm{ab}$ & $2.7 \mathrm{c}$ & 2.3 & 3.5 & $24.0 \mathrm{~b}$ \\
\hline 'Troyer' citrange & - & - & $7.2 \mathrm{~b}$ & $6.6 \mathrm{a}$ & $3.9 \mathrm{bc}$ & 2.8 & 5.1 & $25.5 b$ \\
\hline 'Rangpur' lime & - & - & $15.5 \mathrm{a}$ & $2.6 \mathrm{~b}$ & $5.6 \mathrm{ab}$ & 0.9 & 4.5 & $29.0 \mathrm{~b}$ \\
\hline 'Volkamer' lemon & - & - & $12.6 \mathrm{a}$ & $2.4 \mathrm{~b}$ & $6.7 \mathrm{a}$ & 2.7 & 3.7 & $27.5 b$ \\
\hline 'Flying Dragon' trifoliate orange & - & - & $10.6 \mathrm{ab}$ & $6.2 \mathrm{a}$ & $5.1 \mathrm{ab}$ & 11.4 & 6.1 & $40.0 \mathrm{a}$ \\
\hline $\mathrm{P}$ & - & - & 0.0356 & 0.0248 & 0.0275 & 0.22 & 0.11 & 0.0274 \\
\hline
\end{tabular}

${ }^{(1)}$ Means followed by equal letters, in the columns, do not differ significantly by Duncan's multiple range test, at $5 \%$ probability.

Table 2. Alternate bearing index of 'Oneco' mandarin grafted onto six different rootstocks grown in Butiá, Rio Grande do Sul state, Brazil ${ }^{(1)}$.

\begin{tabular}{|c|c|c|c|c|c|c|c|c|}
\hline Rootstock & $2001 / 2003$ & $2002 / 2004$ & $2003 / 2005$ & $2004 / 2006$ & $2005 / 2007$ & $2001 / 2004$ & $2004 / 2007$ & $2001 / 2007$ \\
\hline 'Swingle' citrumelo & $0.66 \mathrm{ab}$ & $0.62 \mathrm{ab}$ & $0.29 b$ & 0.30 & 0.59 & $0.59 \mathrm{abc}$ & 0.43 & $0.53 b$ \\
\hline 'Caipira' orange & $0.62 \mathrm{ab}$ & $0.58 \mathrm{ab}$ & $0.28 \mathrm{ab}$ & 0.29 & 0.51 & $0.54 \mathrm{bcd}$ & 0.40 & $0.51 \mathrm{~b}$ \\
\hline 'Troyer' citrange & $0.44 \mathrm{~b}$ & $0.35 \mathrm{c}$ & $0.17 \mathrm{~b}$ & 0.30 & 0.51 & $0.34 \mathrm{~d}$ & 0.40 & $0.38 \mathrm{~b}$ \\
\hline 'Rangpur' lime & $0.78 \mathrm{a}$ & $0.71 \mathrm{a}$ & $0.44 \mathrm{a}$ & 0.44 & 0.63 & $0.72 \mathrm{ab}$ & 0.52 & $0.71 \mathrm{a}$ \\
\hline 'Volkamer' lemon & $0.76 \mathrm{a}$ & $0.73 \mathrm{a}$ & $0.47 \mathrm{a}$ & 0.55 & 0.76 & $0.69 \mathrm{a}$ & 0.64 & $0.73 \mathrm{a}$ \\
\hline 'Flying Dragon' trifoliate orange & $0.44 b$ & $0.35 b c$ & $0.17 \mathrm{~b}$ & 0.30 & 0.51 & $0.34 \mathrm{~cd}$ & 0.40 & $0.37 \mathrm{~b}$ \\
\hline $\mathrm{P}$ & 0.0202 & 0.0014 & 0.0054 & 0.1403 & 0.1521 & 0.0013 & 0.1399 & 0.0011 \\
\hline
\end{tabular}

${ }^{(1)}$ Means followed by equal letters, in the columns, do not differ significantly by Duncan's multiple range test, at $5 \%$ probability. 
Production efficiency was influenced by rootstocks, except for the last two years of evaluation. Highest cumulative production efficiency was observed, from 2003 to 2007, for trees grafted onto 'Flying Dragon', despite low yields. Therefore, this rootstock has potential for high-density plantings of citrus cultivars with characteristics similar to 'Oneco', in spite of previous reports with disappointing results regarding this rootstock (Wheaton et al., 1991). Cantuarias-Avilés et al. (2010) also found high production efficiency when working with the cultivar Okitsu satsuma.

Vegetative growth, which was measured in January 2008, was influenced by rootstocks (Table 3). Trunk perimeter and canopy height were highest in trees budded onto 'Caipira' orange, while canopy volume and CPA were highest on 'Caipira' orange and 'Swingle' citrumelo trees. 'Flying Dragon' trifoliate trees had the lowest vegetative growth, with a $37 \%$ decrease in tree height, a $75 \%$ decrease in canopy volume, a $62 \%$ decrease in the projected canopy area, and a $59 \%$ decrease in trunk perimeter in comparison to the most

Table 3. Tree height, volume, canopy projection area (CPA) and trunk perimeter of 'Oneco' mandarin grafted onto six different rootstocks grown in Butiá, Rio Grande do Sul state, Brazil $^{(1)}$.

\begin{tabular}{|c|c|c|c|c|}
\hline Rootstocks & $\begin{array}{l}\text { Tree } \\
\text { height } \\
(\mathrm{m})\end{array}$ & $\begin{array}{c}\text { Canopy } \\
\text { volume } \\
\left(\mathrm{m}^{3}\right)\end{array}$ & $\begin{array}{l}\text { CPA } \\
\left(\mathrm{m}^{2}\right) \\
\end{array}$ & $\begin{array}{c}\text { Trunk } \\
\text { perimeter } \\
(\mathrm{cm})\end{array}$ \\
\hline 'Swingle' citrumelo & $3.62 b$ & $11.61 \mathrm{a}$ & $4.78 \mathrm{a}$ & $34.5 b$ \\
\hline 'Caipira' orange & $3.81 \mathrm{a}$ & $11.70 \mathrm{a}$ & $4.62 \mathrm{ab}$ & $41.5 \mathrm{a}$ \\
\hline 'Troyer' citrange & $3.59 \mathrm{~b}$ & $9.68 \mathrm{ab}$ & $3.97 \mathrm{bc}$ & $34.8 \mathrm{~b}$ \\
\hline 'Rangpur' lime & $3.28 \mathrm{c}$ & $8.12 b c$ & $3.58 \mathrm{~cd}$ & $33.4 \mathrm{bc}$ \\
\hline 'Volkamer' lemon & $3.29 \mathrm{c}$ & $6.88 \mathrm{c}$ & $3.05 \mathrm{~d}$ & $31.4 \mathrm{c}$ \\
\hline 'Flying Dragon' trifoliate orange & $2.39 \mathrm{~d}$ & $2.88 \mathrm{~d}$ & $1.81 \mathrm{e}$ & $17.1 \mathrm{~d}$ \\
\hline $\mathrm{P}$ & $<0.0001$ & $<0.0001$ & $<0.0001$ & $<0.0001$ \\
\hline
\end{tabular}

vigorous rootstocks. Similar vegetative responses of trees grafted on 'Rangpur' lime and 'Volkamer' lemon were found in previous studies (Parente et al., 1993; Georgiou, 2000; Stenzel et al., 2003). However, Parente et al. (1993) did not find differences in tree height or trunk circumferences for 'Ponkan' mandarin trees budded onto 'Caipira' orange, 'Rangpur' lime, 'Volkamer' lemon, 'Swingle' citrumelo or 'Troyer' citrange.

Plants grafted on 'Swingle' had greater vegetative growth than those on 'Rangpur' lime, probably due to the edaphoclimatic conditions in which the present study took place, with colder winters, since 'Rangpur' lime is sensitive to cold and 'Swingle' citrumelo shows some cold resistance (Castle, 1987). Parente et al. (1993), Georgiou (2000), Espinoza-Núñez et al. (2007), and Mourão Filho et al. (2007) did not find any differences among these rootstocks.

'Oneco' trees budded onto citrange 'Troyer' had a lower CPA than trees on 'Swingle'. Schäfer et al. (2001b), working with eight-year-old 'Montenegrina' trees, under the same environmental conditions, did not find differences in CPA between these rootstocks.

The reduction in vegetative growth observed in trees grafted on 'Flying Dragon' indicates the dwarfing characteristics of this rootstock, which is reported to maintain plant height under $2.5 \mathrm{~m}$ (Cheng \& Roose, 1995). These plants showed similar vegetative characteristics to eight-year-old 'Monte Parnaso' orange (Reis et al., 2008) and ten-year-old 'Michal' mandarin (Brugnara et al., 2009) trees in the same orchard. Canopy height and volume reduction of plants budded onto 'Flying Dragon', in comparison to 'Troyer', are similar to the reduction observed by Roose (1986) for 'Valencia' orange.

Fruit quality was significantly influenced by rootstock, except for JC (Table 4). Fruit picked from

Table 4. Total soluble solids (TSS), titratable acidity (TA), TSS:TA ratio, juice content (JC), diameter (D), lenght (L), L:D ratio, and average fruit mass $(\mathrm{M})$ of 'Oneco' mandarin grafted onto six different rootstocks grown in Butiá, Rio Grande do Sul State, Brazil (averages from 2002/2007) ${ }^{(1)}$.

\begin{tabular}{|c|c|c|c|c|c|c|c|c|}
\hline Rootstock & $\begin{array}{l}\text { TSS } \\
(\%)\end{array}$ & $\begin{array}{l}\text { TA } \\
(\%)\end{array}$ & TSS:TA & $\begin{array}{c}\mathrm{JC} \\
(\%)\end{array}$ & $\begin{array}{c}\mathrm{D} \\
(\mathrm{mm})\end{array}$ & $\begin{array}{c}\mathrm{L} \\
(\mathrm{mm})\end{array}$ & $\mathrm{L}: \mathrm{D}$ & $\begin{array}{l}\text { M } \\
(\mathrm{g})\end{array}$ \\
\hline 'Swingle' citrumelo & $8.8 \mathrm{a}$ & $0.64 b$ & $15.1 \mathrm{~cd}$ & 41.2 & $75.0 \mathrm{c}$ & $57.7 \mathrm{c}$ & $0.771 b$ & $164.9 \mathrm{c}$ \\
\hline 'Caipira' orange & $8.5 b$ & $0.55 \mathrm{~cd}$ & $17.0 \mathrm{ab}$ & 40.6 & $76.6 b c$ & $58.8 \mathrm{bc}$ & $0.769 b$ & $173.0 \mathrm{bc}$ \\
\hline 'Troyer' citrange & $8.9 \mathrm{a}$ & $0.56 \mathrm{c}$ & $17.1 \mathrm{ab}$ & 41.3 & $75.3 \mathrm{c}$ & $58.0 \mathrm{c}$ & $0.771 \mathrm{~b}$ & $167.5 \mathrm{c}$ \\
\hline 'Rangpur' lime & $7.7 \mathrm{c}$ & $0.53 \mathrm{~cd}$ & $15.5 \mathrm{bc}$ & 41.2 & $77.3 \mathrm{ab}$ & $60.0 \mathrm{ab}$ & $0.777 \mathrm{~b}$ & $181.9 \mathrm{ab}$ \\
\hline 'Volkamer' lemon & $7.9 \mathrm{c}$ & $0.49 d$ & $17.4 \mathrm{a}$ & 39.5 & $78.5 \mathrm{a}$ & $61.1 \mathrm{a}$ & $0.779 b$ & $187.1 \mathrm{a}$ \\
\hline 'Flying Dragon' trifoliate orange & $8.8 \mathrm{a}$ & $0.72 \mathrm{a}$ & $13.8 \mathrm{~d}$ & 41.5 & $70.6 \mathrm{~d}$ & $55.9 \mathrm{~d}$ & $0.794 \mathrm{a}$ & $145.4 \mathrm{~d}$ \\
\hline $\mathrm{P}$ & $<0.0001$ & $<0.0001$ & 0.0009 & 0.22 & $<0.0001$ & 0.0002 & 0.0099 & $<0.0001$ \\
\hline
\end{tabular}

${ }^{(1)}$ Means followed by equal letters, in the columns, do not differ significantly by Duncan's multiple range test, at $5 \%$ probability. 
'Flying Dragon', 'Swingle', and 'Troyer' rootstocks had the highest TSS contents. 'Flying Dragon' also had the highest TA content, whereas fruit from 'Volkamer' lemon had the lowest, which resulted in the highest and lowest TSS:TA ratios, respectively. Georgiou (2000), Espinoza-Núñez et al. (2007), Mourão Filho et al. (2007), and Brugnara et al. (2009) also found lower content of soluble solids in citrus grafted on 'Rangpur' lime in comparison to citrus budded onto 'Swingle', as well as higher TSS contents in 'Ponkan' grafted on $P$. trifoliata in comparison to trees on 'Rangpur' lime and 'Volkamer' lemon (Stenzel et al., 2003). However, Yonemoto et al. (2004) observed that 'Shirakawa' satsuma grafted on 'Flying Dragon' had higher soluble solids in comparison to those on P. trifoliata, independently of the fruit load on trees. Rootstocks had no effect on JC, as reported by other authors (Koller et al., 2000; Pérez-Zamora et al., 2002; Castle et al., 2007; Espinoza-Núñez et al., 2007; Mourão Filho et al., 2007; Brugnara et al., 2009).

Mandarins harvested from plants on 'Flying Dragon' had the smallest fruit among the tested rootstocks, while 'Volkamer' lemon produced the largest and heaviest ones (Table 4). Fruits from trees grown on 'Flying Dragon' were more spherical than those on the other tested rootstocks, which were more oblong.

The highest average fruit weight for plants budded on 'Volkamer' lemon is similar to that found for 'Nova' tangerine (Georgiou, 2000), although, in the present work, there were no differences in fruit diameter for 'Rangpur', 'Troyer', 'Swingle', and 'Volkamer' rootstocks. The effect of rootstocks on the L:D ratio was also observed by Koller et al. (2000) for 'Hamlin' orange, under the same climatic conditions.

\section{Conclusions}

1. The most adequate rootstocks for mandarin 'Oneco' in the tested region are 'Swingle' citrumelo and 'Troyer' citrange, regarding fruit yield and quality.

2. Plants grafted onto 'Flying Dragon' rootstock have higher production efficiency, in spite of lower canopy volume.

\section{Acknowledgements}

To Programa de Pós-graduação em Fitotecnia of Universidade Federal do Rio Grande do Sul, to Fazenda Panoramas Citrus; to Conselho Nacional de Desenvolvimento Científico e Tecnológico, to Coordenação de Aperfeiçoamento de Pessoal de Nível Superior, and to Fundação de Amparo à Pesquisa do Estado do Rio Grande do Sul, for financial support; to Dr. Otto Carlos Koller, for guidance and for the establishment and management of the orchard during the initial years; and to Dr. Rebecca Darnell, from the Horticultural Sciences Department of the University of Florida, for revising this paper.

\section{References}

AMARO, A.A.; CASER, D.V. Diversidade do mercado de tangerinas. Informações Econômicas, v.33, p.51-67, 2003.

BERGAMASCHI, H.; GUADAGNIN, M.R.; CARDOSO, L.S.; SILVA, M.I.G. Clima da estação experimental da UFRGS (e região de abrangência). Porto Alegre: UFRGS, 2003. 78p.

BRUGNARA, E.C.; SCHWARZ, S.F.; KOLLER, O.C.; BENDER, R.J.; WEILER, R.L.; GONZATTO, M.P.; SCHÄFER, G.; MARTINS, F.T.; LIMA, J.G. de. Porta-enxertos para a tangerineira 'Michal' no Rio Grande do Sul. Ciência Rural, v.39, p.1374-1379, 2009.

CANTUARIAS-AVILÉS, T.; MOURÃO FILHO, F.A.A.; STUCHI, E.S.; SILVA, S.R.; ESPINOZA-NÚÑEZ, E. Tree performance and fruit yield and quality of 'Okitsu' Satsuma mandarin grafted on 12 rootstocks. Scientia Horticulturae, v.123, p.318-322, 2010.

CASTLE, W.S. Citrus rootstocks. In: ROM, R.C.; CARLSON, R.F. (Ed.). Rootstocks for fruits crops. New York: John Wiley and Sons, 1987. p.361-399.

CASTLE, W.S.; BALDWIN, J.C.; MURARO, R.P. 'Hamlin' orange trees on Flying Dragon trifoliate orange, Changsha mandarin, or Koethen Sweet Orange x Rubidoux trifoliate orange citrange rootstock at three in-row spacings in a flatwoods site. Proceedings of the Florida State Horticultural Society, v.120, p.92-96, 2007.

CHENG, F.S.; ROOSE, M.L. Origin and inheritance of dwarfing by the Citrus rootstock Poncirus trifoliate 'Flying Dragon'. Journal of the American Society for Horticultural Science, v.120, p.286-291, 1995.

ESPINOZA-NUÑEZ, E.; MOURÃO FILHO, F. de A.A.; STUCHI, E.S. Desenvolvimento vegetativo, produção e qualidade de frutos da tangerina 'Fremont' sobre quatro porta-enxertos. Revista Brasileira de Fruticultura, v.29, p.308-312, 2007.

ESPINOZA-NUÑEZ, E.; MOURÃO FILHO, F. de A.A.; STUCHI, E.S.; ORTEGA, E.M.M. Desenvolvimento e produtividade da tangerina 'Fairchild' sobre quatro porta-enxertos. Ciência Rural, v.38, p.1553-1557, 2008.

GEORGIOU, A. Performance of 'Nova' mandarin on eleven rootstocks in Cyprus. Scientia Horticulturae, v.84, p.115-126, 2000.

HODGSON, R.W. Horticultural varieties of citrus. In: REUTHER, W.; WEBBER, H.J.; BATCHELOR, L.D. (Ed.). The citrus industry. Riverside: University of California, 1967. p.431-591. 
KOLLER, O.C. (Coord.). Citricultura: cultura de tangerineiras: tecnologia de produção, pós-colheita e industrialização. Porto Alegre: Rígel, 2009. 400p.

KOLLER, O.L.; SOPRANO, E.; COSTA, A.C.Z. de. Avaliação de porta-enxertos para laranjeira 'Hamlin' em Santa Catarina. Revista Ceres, v.47, p.325-336, 2000.

MOURÃO FILHO, F. de A.A.; ESPINOZA-NUÑEZ, E.; STUCHI, E.S.; ORTEGA, E.M.M. Plant growth, yield, and fruit quality of 'Fallglo' and 'Sunburst' mandarins on four rootstocks. Scientia Horticulturae, v.114, p.45-49, 2007.

PARENTE, T.V.; WECHESLER, F.S.; BORGO, L.A.; REZENDE, L.P. Comportamento da tangerineira 'Ponkan' (Citrus reticulata Blanco) sobre 14 porta-enxertos no Distrito Federal. Revista Brasileira de Fruticultura, v.15, p.35-41, 1993.

PÉREZ-ZAMORA, O.; MEDINA-URRUTIA, V.; BECERRA-RODRÍGUEZ, S. Crecimiento y rendimiento de naranja Valencia injertada en 16 portainjertos de cítricos establecidos en suelo calcimórfico, y calidad del jugo. Agrociencia, v.36, p.137-148, 2002.

POMPEU JÚNIOR, J. Porta-enxertos. In: MATTOS JÚNIOR, D. de; DE NEGRI, J.D.; PIO, R.M.; POMPEU JÚNIOR, J. (Ed.). Citros. Campinas: Instituto Agronômico de Campinas, 2005. p.61-104.

REIS, B.; KOLLER, O.C.; SCHWARZ, S.F.; THEISEN, S.; SARTORI, I.A.; NICHELE, F.S.; LORSCHEITER, R.; PETRY, H.B. Produção de frutos e incidência de cancro cítrico em laranjeiras 'Monte Parnaso' enxertadas sobre sete porta-enxertos. Ciência Rural, v.38, p.672-678, 2008.

ROOSE, M.L. Dwarfing rootstock forCitrus. In: INTERNATIONAL CONGRESS OF CITRUS NURSERYMEN, 2., 1986, Riverside. Proceedings. Riverside: International Society of Citrus Nurserymen, 1986. p.1-8.

SARTORI, I.A.; SCHÄFER, G.; SCHWARZ, S.F.; KOLLER, O.C. Épocas de maturação de tangerinas na depressão central do Rio Grande do Sul. Revista Brasileira de Fruticultura, v.20, p.313-322, 1998.
SCHÄFER, G.; BASTIANEL, M.; DORNELLES, A.L.C. Porta-enxertos utilizados na citricultura. Ciência Rural, v.31, p.723-733, 2001a.

SCHÄFER, G.; PANZENHAGEN, N.V.; SARTORI, I.A.; SCHWARZ, S.F.; KOLLER, O.C. Produção e desenvolvimento da tangerineira-'montenegrina' propagada por enxertia e estaquia, no Rio Grande do Sul. Revista Brasileira de Fruticultura, v.23, p.668-672, 2001b.

SMITH, M.W.; SHAW, R.G.; CHAPMAN, J.C.; OWEN-TURNER, J.; LEE, L.S.; MCRAE, K.B.; JORGENSEN, K.R.; MUNGOMERY, W.V. Long-term performance of 'Ellendale' mandarin on seven commercial rootstocks in sub-tropical Australia. Scientia Horticulturae, v.102, p.75-89, 2004.

STENZEL, N.M.C.; NEVES, C.S.V.J.; GOMES, J.C.; MEDINA, C.C. Performance of 'Ponkan' mandarin on seven rootstocks in southern Brazil. Hortscience, v.38, p.176-178, 2003.

STUCHI, E.S.; ESPINOZA-NÚÑEZ, E.; MOURÃO FILHO, F. de A.A.; ORTEGA, E.M.M. Vigor, produtividade e qualidade de frutos de quatro tangerineiras e híbridos sobre quatro porta-enxertos. Revista Brasileira de Fruticultura, v.30, p.741-747, 2008.

UNITED STATES DEPARTMENT OF AGRICULTURE. Soil Survey Staff. Soil taxonomy: a basic system of soil classification for making and interpreting soil survey. 2.ed. Washington: USDA, 1999. 871p. (USDA. Agriculture handbook, 436).

WHEATON, T.A.; CASTLE, W.S.; WHITNEY, J.D.; TUCKER, D.P.H. Performance of citrus scion cultivars and rootstocks in a high-density planting. Hortscience, v.26, p.837-840, 1991.

YONEMOTO, Y.; MATSUMOTO, K.; FURUKAWA, T.; ASAKAWA, M.; OKUDA, H.; TAKAHARA, T. Effects of rootstock and crop load on sap flow rate in branches of 'Shirakawa Satsuma' mandarin (Citrus unshiu Marc.). Scientia Horticulturae, v.102, p.295-300, 2004.

ZEKRI, M. Citrus rootstock affect scion nutrition, fruit quality, growth, yield and economical return. Fruits, v.55, p.231-239, 2000 .

Received on March 14, 2011 and accepted on April 20, 2011 